\title{
Integration between genetic and chemical control on the progress of Asian soybean rust and yield
}

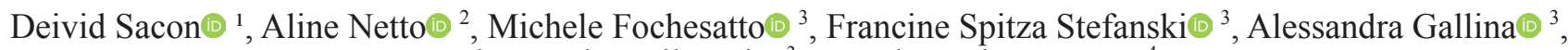 \\ Paola Mendes Milanesi@ ${ }^{3}$, Leandro Luiz Borges $\oplus^{4}$
}

\begin{abstract}
${ }^{1}$ Instituto de Biotecnologia Aplicada à Agropecuária, Universidade Federal de Viçosa. Viçosa-MG, Brasil, CEP 36.570-900. ${ }^{2}$ Grupo ABC Agrícola, Sapezal-MT, Brasil. ${ }^{3}$ Universidade Federal da Fronteira Sul - Campus Erechim, CEP 99.700-970, Erechim-RS, Brasil. ${ }^{4}$ Universidade do Estado de Minas Gerais, Unidade de Passos, CEP 37900-106, Passos-MG, Brasil.
\end{abstract}

Autor para correspondência: Deivid Sacon(deividsacon@hotmail.com)

Data de chegada: 07/03/2019. Aceito para publicação em: 19/12/2019.

$10.1590 / 0100-5405 / 220951$

\section{ABSTRACT}

Sacon, D.; Netto, A.; Fochesatto, M.; Stefanski, F.S.; Gallina, A.; Milanesi, P.M.; Borges, L.L. Integration between genetic and chemical control on the progress of Asian soybean rust and yield. Summa Phytopathologica, v.46, n.3, p.198-204, 2020.

The objective of this study was to evaluate the genetic control integrated to the chemical control of Asian soybean rust (ASR) and the effects of these measures on crop yield. The experiment was conducted in Erechim, Rio Grande do Sul State, Brazil, in 2016/17 and 2017/18 crop years, under a randomized block design, in a subdivided plot scheme (cultivars in the plots and fungicides in the subplots), with four replicates. The following cultivars were used: BMX Vanguarda (without ASR tolerance); TMG 7062; TMG 7262, and TMG 7161, tolerant to ASR (Inox ${ }^{\mathrm{TM}}$ Technology cultivars). The fungicides used were: T1) control (without application of fungicides); T2) azoxystrobin + benzovindiflupyr; T3) difenoconazole + cyproconazole; T4) trifloxystrobin + prothioconazole, and T5) epoxiconazole + fluxapyroxad + pyraclostrobin. Four fungicide applications were carried out at the V6, R1, R5.1 and R6 stages. During the experiment, for the calculation of the area under disease progress curve (AUDPC), disease severity was assessed at 7-day intervals in a random sample of 10 trifolia per plot. After harvest, yield components were determined: number of grains per plant, thousand grain weight (g), and yield ( $\left.\mathrm{kg} \mathrm{ha}^{-1}\right)$. In 2017/18 crop year, the fungicide difenoconazole + cyproconazole was not efficient for ASR control. The soybean cultivars TMG 7062, TMG 7161 and TMG 7261 delayed the disease progression; however, only TMG 7161 presented tolerance in the presence of the inoculum in 2016/17 and 2017/18 crop years. The association between chemical and genetic control is shown to be efficient for ASR control.

Keywords: Glycine max L. Merrill, Phakopsora pachyrhizi Sydow \& Sydow, integrated measures, chemical control, genetic resistance.

\section{RESUMO}

Sacon, D.; Netto, A.; Fochesatto, M.; Stefanski, F.S.; Gallina, A.; Milanesi, P.M.; Borges, L.L. Integração entre controle genético e químico no progresso da ferrugem asiática e na produtividade da soja. Summa Phytopathologica, v.46, n.3, p.198-204, 2020.

Objetivou-se avaliar o controle genético integrado ao controle químico da ferrugem asiática da soja (FAS) e os efeitos dessas medidas sobre a produtividade da cultura. O experimento foi conduzido em Erechim/RS, nas safras 2016/17 e 2017/18, sob delineamento de blocos casualizados, em esquema de parcela subdividida (cultivares, nas parcelas; e fungicidas, nas subparcelas), com quatro repetições. Foram utilizadas as seguintes cultivares: BMX Vanguarda (sem tolerância à FAS); TMG 7062; TMG 7262; e TMG 7161, tolerantes à FAS (cultivares com tecnologia Inox ${ }^{\mathrm{TM}}$ ). Os fungicidas utilizados foram: T1) testemunha (sem aplicação de fungicidas); T2) azoxistrobina + benzovindiflupyr; T3) difenoconazol + ciproconazol; T4) trifloxistrobina + protioconazol; e T5) epoxiconazol + fluxapiroxade + piraclostrobina. Foram realizadas quatro aplicações de fungicidas nos estádios V6; R1; R5.1; e R6. Durante a condução do experimento, para o cálculo da área abaixo da curva de progresso da doença (AACPD), avaliou-se a severidade da doença, com intervalos de 7 dias, em uma amostra aleatória de 10 trifólios por parcela. Após a colheita, determinou-se os componentes de rendimento: número de grãos por planta, peso de mil grãos (g), e a produtividade $\left(\mathrm{kg} \mathrm{ha}^{-1}\right)$. Na safra 2017/18 o fungicida difenoconazol + ciproconazol não foi eficiente para o controle da FAS. As cultivares de soja TMG 7062, TMG 7161 e TMG 7261 retardaram o progresso da doença, entretanto somente a cultivar TMG 7161 apresentou tolerância sob a presença do inóculo nas safras 2016/17 e 2017/18. A associação entre controle químico e genético mostra-se eficiente no controle da FAS.

Palavras-chave: Glycine max L. Merrill, Phakopsora pachyrhizi Sydow \& Sydow, medidas integradas, controle químico, resistência genética.

Brazil is the largest soybean (Glycine max L. Merrill) producer in the world. Diseases are one of the major biotic factors affecting soybean yield, and the main foliar disease is Asian soybean rust, the etiological agent of which is Phakopsora pachyrhizi Sydow \& Sydow, a biotrophic fungus that can cause losses ranging from $30 \%$ to $75 \%(13,19)$.

The use of fungicides is the main form to control Asian soybean rust (ASR). Although effective, chemical control requires proper monitoring and application at the optimal time. Genetic resistance is the most economical tool to control ASR, besides leaving no residues in the environment $(16,22)$.

Development of ASR-resistant genotypes harboring vertical resistance genes has been a major challenge for research. The difficulty in identifying resistant cultivars lies in the several races of $P$. pachyrrizi showing multiple virulence alleles $(17,18)$. 
Considering ASR-specific resistance, seven Rpp genes were mapped and identified (Rppl-7). Incompatible reactions are expressed by the Rppl gene, while the other genes act to reduce disease development by producing reddish-brown lesions (RB lesions). Compatible reactions between soybean and $P$. pachyrhizi produce sporulating lesions called TAN lesions (22). Resulting from quantitative, specific and heritable traits, tolerance allows the pathogen to infect, colonize and multiply in the host. However, the plant tolerates the pathogen without significant losses in productivity and quality, resembling a healthy host (18).

Tolerant cultivars have symptoms similar to those of a susceptible cultivar but show greater productive stability when infected by a pathogen. Thus, cultivars showing this trait may require fewer fungicide applications, reducing the dependence on pesticide use, as well as the production cost (18). In this perspective, adoption of integrated management for ASR, such as sanitary void, genetic resistance and fungicides, is necessary to efficiently control this disease $(5,22)$.

Due to the importance of soybean and Asian soybean rust, the objective of this study was to evaluate genetic control integrated with chemical control of ASR and the effects of these measures on soybean yield.

\section{MATERIAL AND METHODS}

The experiment was carried out in the municipality of Erechim, Rio Grande do Sul State, Brazil, in 2016/17 and 2017/18 crop years. The local soil is classified as Red Latosol (Oxisol) (6). Precipitation (mm) and temperature $\left({ }^{\circ} \mathrm{C}\right)$ during the soybean cycle where the experiment was conducted are shown in Figure 1.

A randomized complete block design in split plot with 4 replicates was adopted. Each plot was $12.0 \mathrm{~m}$ wide and $30.0 \mathrm{~m}$ long, totaling 360

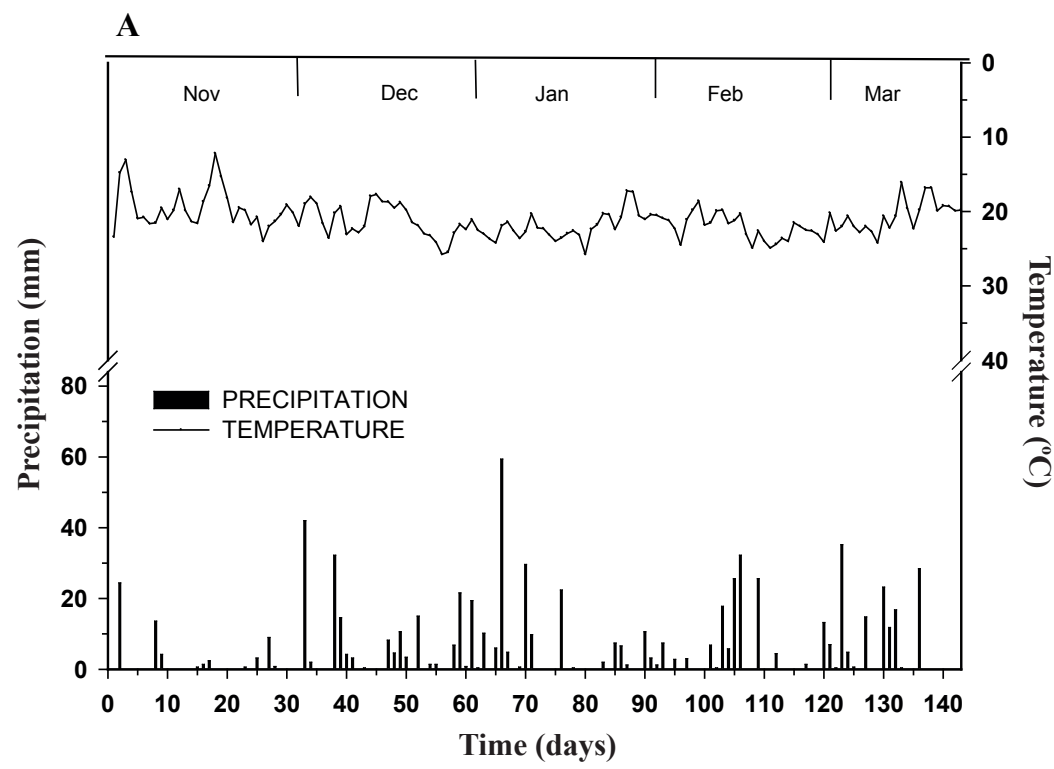

B

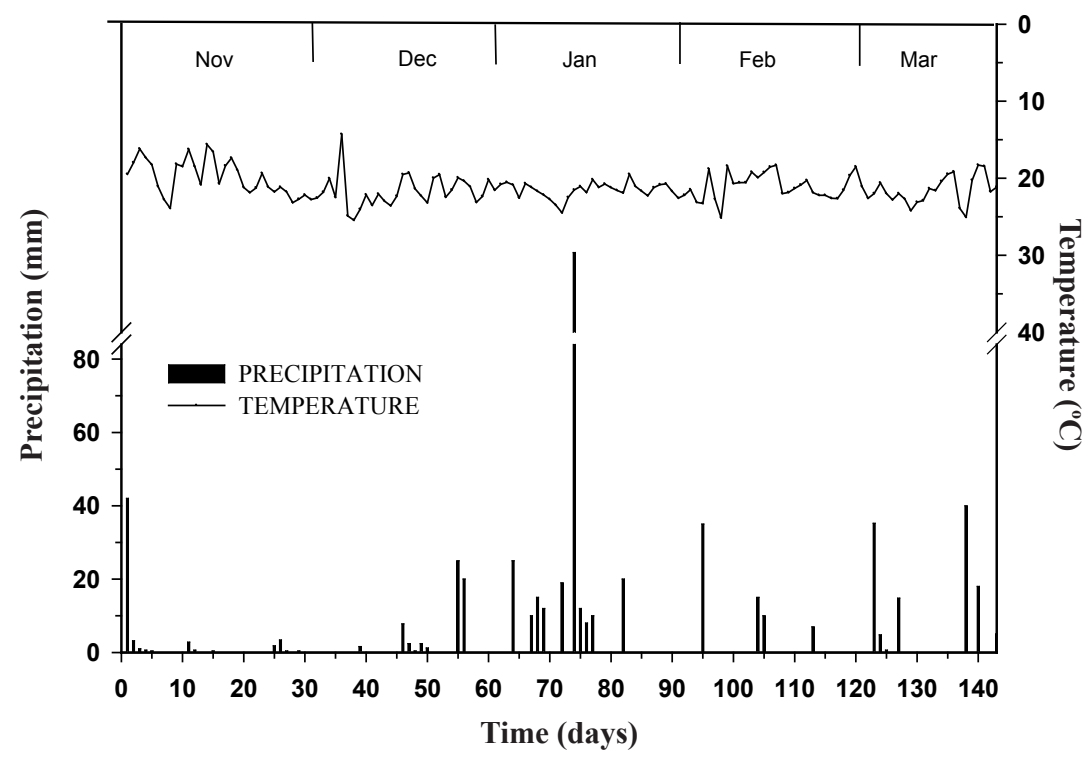

Figure 1. Temperature $\left({ }^{\circ} \mathrm{C}\right)$ and precipitation $(\mathrm{mm})$ between November and March of 2016/17 (A) and 2017/18 (B) soybean crop years in Erechim Municipality, Rio Grande do Sul State, Brazil. Source: www.inmet.gov.br (11). 
$\mathrm{m}^{2}$, while the subplot was $3.0 \mathrm{~m}$ wide and $6.0 \mathrm{~m}$ long, totaling $18.0 \mathrm{~m}^{2}$, and the useful area was $4.0 \mathrm{~m}^{2}$.

The main plots received the cultivars BMX Vanguarda (BMX V.), TMG 7262, TMG 7062 and TMG 7161 (Inox ${ }^{\text {TM }}$ Technology), maturation cycles 6.0, 6.2, 6.2 and 5.9, respectively. In the subplots, the following fungicide treatments were distributed: T1) control, without application of fungicides; T2) azoxystrobin + benzovindiflupyr $(60+$ $30 \mathrm{~g}$ a.i. $\left.\mathrm{ha}^{-1}\right)$; T3) difenoconazole + cyproconazole $(75+45 \mathrm{~g}$ a.i. ha$\left.{ }^{1}\right)$; T4) trifloxystrobin + prothioconazole $\left(60+70 \mathrm{~g} \mathrm{a.i.} \mathrm{ha}^{-1}\right)$; and T5) epoxiconazole + fluxapyroxad + pyraclostrobin $\left(50+50+81 \mathrm{~g}\right.$ a.i. ha $\left.{ }^{-1}\right)$.

Sowing was performed on November $25^{\text {th }}, 2016$, and November $23^{\text {rd }}, 2017$, with a precision seeder in 6 rows per plot, keeping 0.5 $\mathrm{m}$ spacing between rows and density of 14 seeds per linear meter to obtain a population of 240,000 plants/ha. Fertilization was obtained with mineral fertilizer N-P-K, formula $00-20-20$, at the proportion of $350 \mathrm{~kg} \mathrm{ha}^{-1}$.

During the crop development, four fungicide applications were performed in the subplots, constituting the replicates of each treatment, in stages (7): V6, R1, R5.1 and R6. The applications were carried out with a $\mathrm{CO}_{2}$ pressurized coastal sprayer, pressure of $30 \mathrm{Ib} \mathrm{in}^{-2}$, equipped with a $2 \mathrm{~m}$-long bar and TXA $8002 \mathrm{VK}$ conical tip, and $0.5 \mathrm{~m}$ spacing between tips set at a flow rate of $150 \mathrm{~L} \mathrm{ha}^{-1}$.

Assessments of disease progress started when the first symptoms of Asian soybean rust were identified. Thus, ten leaf samples (trifolium) were analyzed per plot at 7-day intervals and compared according to the diagrammatic scale of Canteri et al. (4) for disease severity assessment. The area under disease progress curve (AUDPC) was determined according to the equation proposed by Campbell and Madden (3). The percentage of control (\%) in each cultivar was also calculated.

Yield components were also determined: number of grains per plant (NGP) and Thousand Grain Weight (TGW), expressed as grams (g) (2). To quantify NGP, five plants per subplot were randomly collected before harvest. TGW for each replicate was then added to the total grain weight of each treatment in order to obtain the yield $\left(\mathrm{kg} \mathrm{ha}^{-1}\right)$.

After harvest, the plants present in the useful area of each subplot were tracked with a stationary plotter to estimate the yield $\left(\mathrm{kg} \mathrm{ha}^{-1}\right)$ from each treatment. Before TGW determination, a 50-g grain sample from each subplot was used for moisture content determination based on the $105{ }^{\circ} \mathrm{C}$ air drying oven method (2). Seed moisture content from each sample was corrected to $13 \%$. Yield and its components, AUDPC and control (\%) data were submitted to ANOVA using the F-test and, when significant ( $\mathrm{p} \leq 0.05)$, means were compared according to Tukey's test ( $\mathrm{p}$ $\leq 0.05)$. The analysis was performed with the statistical software $R(20)$.

\section{RESULTS AND DISCUSSION}

In 2016/17 crop year, severity was lower than that observed in 2017/18 crop year (Table 1). Average temperature below ideal for the spread of rust was one of the factors that interfered in the disease progress in the first crop year, in addition to intense rainfall. During 2017/18 crop year, a distinct meteorological panorama was observed, which led to similar temperature but less rainfall (23 occurrences with precipitation greater than $0.2 \mathrm{~mm})$, compared to the past season $(53$

Table 1. Area under disease progress curve (AUDPC) and control (\%) of Asian soybean rust for the cultivars BMX Vanguarda (BMX V.), TMG 7062, TMG 7161 and TMG 7262, with or without fungicide applications, in 2016/17 and 2017/18 crop years.

\begin{tabular}{|c|c|c|c|c|c|c|c|c|}
\hline \multirow{3}{*}{ Treat." } & \multicolumn{8}{|c|}{ AUDPC } \\
\hline & \multicolumn{4}{|c|}{$2016 / 17$} & \multicolumn{4}{|c|}{$2017 / 18$} \\
\hline & BMX & TMG & TMG & TMG & BMX & TMG & TMG & TMG \\
\hline Control & $231.3 \mathrm{aAB}^{* *}$ & $180.2 \mathrm{aB}$ & $293.4 \mathrm{aA}$ & $150.5 \mathrm{aB}$ & $415.2 \mathrm{aA}$ & $235.3 \mathrm{aC}$ & $229.2 \mathrm{aC}$ & $282.6 \mathrm{aB}$ \\
\hline $\mathbf{A} \mathbf{B}^{1}$ & $102.0 \mathrm{bA}$ & $30.9 \mathrm{cA}$ & $26.7 \mathrm{bA}$ & $27.7 \mathrm{bA}$ & $176.7 \mathrm{bA}$ & $62.1 \mathrm{cB}$ & $68.2 \mathrm{cB}$ & $54.0 \mathrm{cB}$ \\
\hline $\mathbf{T} \mathbf{P}^{3}$ & $75.7 \mathrm{bA}$ & $46.9 \mathrm{bcA}$ & $57.1 \mathrm{bA}$ & $58.1 \mathrm{bA}$ & $93.6 \mathrm{cA}$ & $56.0 \mathrm{cAB}$ & $58.6 \mathrm{cAB}$ & $43.4 \mathrm{cB}$ \\
\hline $\mathbf{E F P}^{4}$ & $74.3 \mathrm{bA}$ & $27.4 \mathrm{cA}$ & $25.9 \mathrm{bA}$ & $20.4 \mathrm{bA}$ & $122.5 \mathrm{cA}$ & $69.1 \mathrm{cB}$ & $76.1 \mathrm{cB}$ & $51.6 \mathrm{cB}$ \\
\hline \multicolumn{5}{|l|}{$\mathrm{CV}_{1}=56.9 \%$} & \multicolumn{4}{|c|}{$\mathbf{C V}_{1}=20.0 \%$} \\
\hline $\mathrm{CV}_{2}=48.9 \%$ & & & & & \multicolumn{4}{|c|}{$\mathbf{C V}_{2}=16.3 \%$} \\
\hline $\mathrm{DC}^{2}$ & $56.6 \mathrm{aA}$ & $46.9 \mathrm{bcA}$ & $68.1 \mathrm{aA}$ & $76.7 \mathrm{aA}$ & $52.7 \mathrm{bB}$ & $65.0 \mathrm{bA}$ & $65.4 \mathrm{bA}$ & $75.3 \mathrm{bA}$ \\
\hline $\mathbf{T} \mathbf{P}^{3}$ & $67.1 \mathrm{aA}$ & $79.6 \mathrm{abA}$ & $75.2 \mathrm{aA}$ & $74.8 \mathrm{aA}$ & $77.4 \mathrm{aB}$ & $86.5 \mathrm{aAB}$ & $85.8 \mathrm{aAB}$ & $89.5 \mathrm{aA}$ \\
\hline $\mathbf{E F P}^{4}$ & $67.8 \mathrm{aA}$ & $88.7 \mathrm{aA}$ & $88.1 \mathrm{aA}$ & $87.8 \mathrm{aA}$ & $70.4 \mathrm{aB}$ & $83.3 \mathrm{aB}$ & $81.6 \mathrm{aB}$ & $87.5 \mathrm{aB}$ \\
\hline $\mathbf{C V}_{1}=29.0 \%$ & & & & & \multicolumn{4}{|c|}{$\mathbf{C V}_{1}=10.0 \%$} \\
\hline $\mathbf{C V}_{2}=27.7 \%$ & & & & & \multicolumn{4}{|c|}{$\mathbf{C V}_{2}=7.70 \%$} \\
\hline
\end{tabular}

"Treatment. ${ }^{* *}$ Mean values followed by the same lowercase letter in the column and uppercase letter on the line do not differ statistically according to Tukey's test at $5 \%$ probability level. ${ }^{\text {ns }}$ not significant at $5 \%$ level. $\mathrm{CV}_{1}=$ Coefficient of variation of plots; $\mathrm{CV}_{2}=$ Coefficient of variation of sub-plots. ${ }^{1}$ azoxistrobin + benzovindiflupyr (AB); ${ }^{2}$ difenoconazole + cyproconazole (DC); ${ }^{3}$ trifloxistrobin + prothioconazole $(\mathrm{TP}) ;{ }^{4}$ epoxiconazole + fluxapyroxad + pyraclostrobin $($ EFP). 
occurrences) (Figure 1).

In both evaluated crop years, there was a significant interaction between cultivars and fungicides for AUDPC and disease control (\%). Severity was lower in $2016 / 17$, considering the four evaluated cultivars, probably because the first severity assessment was done four days before, compared to the following crop year.

In 2016/17 crop year, the cultivars TMG 7062 and TMG 7262 presented lower AUDPC values, 180.2 and 150.5 units, respectively, in the absence of fungicide application. Treatments including chemical control of ASR resulted in no difference between cultivars. In 2017/18 crop year, TMG 7062 and TMG 7262 were again highlighted for lower AUDPC values, followed by TMG 7061 (Table 1).

In general, in 2016/17 crop year, all tested fungicides provided lower AUDPC, compared to the absence of application (control), but did not differ among each other. The cultivar TMG 7062 was an exception since the fungicides azoxystrobin + benzovindiflupyr, difenoconazole + cyproconazole and trifloxystrobin + prothioconazole showed the best performance.

In 2017/18 crop year (Table 1), higher AUDPC was observed for subplots sprayed with difenoconazole + cyproconazole considering all tested cultivars. The AUDPC did not differ among fungicides, except for azoxystrobin + benzovindiflupyr in BMX Vanguarda. Control subplots, with no fungicide application, had the highest AUDPC values in all tested cultivars. In 2016/17 crop year, in the absence of fungicide application, TMG 7262 presented control of $34.8 \%$, compared to BMX Vanguarda (Table 1). In the following crop year (2017/18), TMG 7262, TMG 7062 and TMG 7161, in the absence of application, presented control levels of $31.8 \%, 44.7 \%$ and $43.7 \%$, respectively, compared to BMX Vanguarda, considering the same treatment. These results show differences in sensitivity among the cultivars evaluated in this study to the fungus $P$. pachyrhizi.

Regarding 2016/17 crop year (Table 1), all used fungicides provided similar control, except the triazole-based fungicides, difenoconazole + cyproconazole, on TMG 7062. In the following crop year (2017/18), fungicides in double (triazole + strobilurin or triazole + carboxamide) and triple (triazole + strobilurin + carboxamide) mixtures again led to the highest control (\%), compared to triazoles alone.

For the variables NGP, TGW (g) and yield $\left(\mathrm{kg} \mathrm{ha}^{-1}\right)$, there was no interaction between the evaluated cultivars and fungicides; therefore, the factors were separated to evidence the performance of cultivars under different treatments (Tables 2 and 3).

BMX Vanguarda and TMG 7161 presented a higher number

Table 2. Number of grains per plant (NGP), thousand grain weight (TGW), and yield for the soybean cultivars BMX Vanguarda (BMX V.), TMG 7062, TMG 7161 and TMG 7262, in response to the application of different fungicides in order to control Asian soybean rust, in 2016/17 crop year.

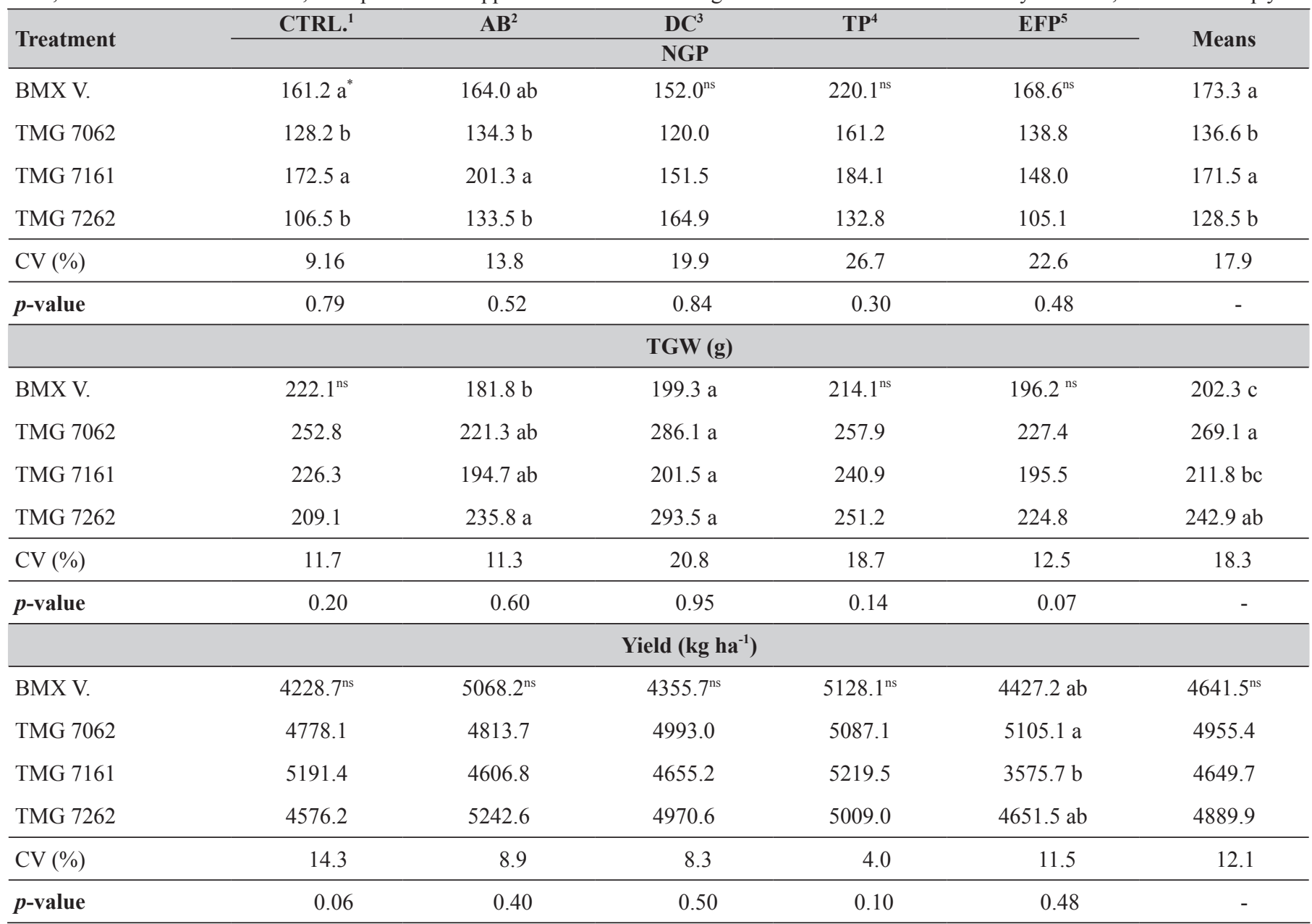

"Mean values followed by the same lowercase letter in the column do not differ statistically according to Tukey's test at 5\% probability level. ${ }^{\text {ns }}$ not significant at $5 \%$ level; CV (\%), coefficient of variation. ${ }^{1}$ Control (CTRL); ${ }^{2}$ azoxistrobin + benzovindiflupyr (AB); ${ }^{3}$ difenoconazole + cyproconazole (DC); ${ }^{4}$ trifloxistrobin + prothioconazole (TP); ${ }^{5}$ epoxiconazole + fluxapyroxad + pyraclostrobin (EFP). 
of grains per plant (NGP) in all treatments showing statistical difference: control (absence of fungicide application); azoxystrobin + benzovindiflupyr, and difenoconazole + cyproconazole. Considering the average treatment evaluation, BMX Vanguarda and TMG 7161 also obtained higher NGP, of 173.3 and 171.5, respectively, while TMG 7062 (136.6) and TMG 7262 (128.5) had lower results (Table 2).

Evaluating TGW in 2016/17 crop year (Table 2), the cultivar TMG was more prominent when receiving azoxystrobin + benzovindiflupyr. TMG 7062 had TGW of $269.1 \mathrm{~g}$, followed by TMG 7262 (242.9 g), TMG 7161 (211.8 g) and BMX Vanguarda (202.3 g). On the other hand, in 2017/18 crop year (Table 3), TMG 7062 presented the highest TGW in all evaluated treatments, ranging from $146.9 \mathrm{~g}$ (control) to $178.8 \mathrm{~g}$ (epoxiconazole + fluxapyroxad + pyraclostrobin).

In 2016/17 crop year, there was no difference in yield between cultivars (Table 2), except when epoxiconazole + fluxapyroxad + pyraclostrobin was used. For this treatment, TMG 7062 had the highest productive capacity $\left(5105.1 \mathrm{~kg} \mathrm{ha}^{-1}\right)$, followed by TMG $7062(5009.0 \mathrm{~kg}$ $\mathrm{ha}^{-1}$ ), BMX Vanguarda (4427.4 $\left.\mathrm{kg} \mathrm{ha}^{-1}\right)$ and TMG $7161\left(3575.7 \mathrm{~kg} \mathrm{ha}^{-1}\right)$.

In $2017 / 18$ crop year (Table 3 ), there was no significant difference between treatments when the fungicides difenoconazole + cyproconazole, trifloxystrobin + prothioconazole and epoxiconazole + fluxapyroxad + pyraclostrobin were applied. Considering the control, cultivars BMX Vanguarda, TMG 7161 and TMG 7062 presented the highest productivity, which was $2829.8,2876.1$ and $2655.9 \mathrm{~kg} \mathrm{ha}^{-1}$, respectively.

When azoxystrobin + benzovindiflupyr was applied, the highest yields were also obtained for cultivars BMX Vanguarda (3456.8 $\mathrm{kg} \mathrm{ha}$ ${ }^{1}$ ), TMG 7062 (3216.0 $\mathrm{kg} \mathrm{ha}^{-1}$ ) and TMG 7161 (3148.3 $\left.\mathrm{kg} \mathrm{ha}^{-1}\right)$. TMG 7262 presented the lowest yield value in the control treatment, which was $2449.9 \mathrm{~kg} \mathrm{ha}^{-1}$. The same was repeated when ASR was controlled with azoxystrobin + benzovindiflupyr (2924.5 kg ha ${ }^{-1}$ ) (Table 3).

Comparison of the performance of cultivars in the absence of fungicide application shows that the largest yield reduction caused by ASR was obtained for TMG 7262 (313.0 $\left.\mathrm{kg} \mathrm{ha}^{-1}\right)$ in 2016/17 crop year. However, in the following crop year, this cultivar showed an intermediate reduction $\left(380.0 \mathrm{~kg} \mathrm{ha}^{-1}\right)$, compared to the other cultivars (Figure 2).

The cultivars TMG 7062 and TMG 7161 showed an intermediate reduction in yield in both crop years, except for TMG 7161 in 2016/17, when no yield reduction was observed. BMX Vanguarda, in 2017/18 crop year, showed greater intolerance to the severity of ASR (Figure 2 ); however, although it was more susceptible to the disease even in

Table 3. Number of grains per plant (NGP), thousand grain weight (TGW), and yield for the soybean cultivars BMX Vanguarda (BMX V.), TMG 7062, TMG 7161 and TMG 7262, in response to the application of different fungicides in order to control Asian soybean rust, in 2017/18 crop year.

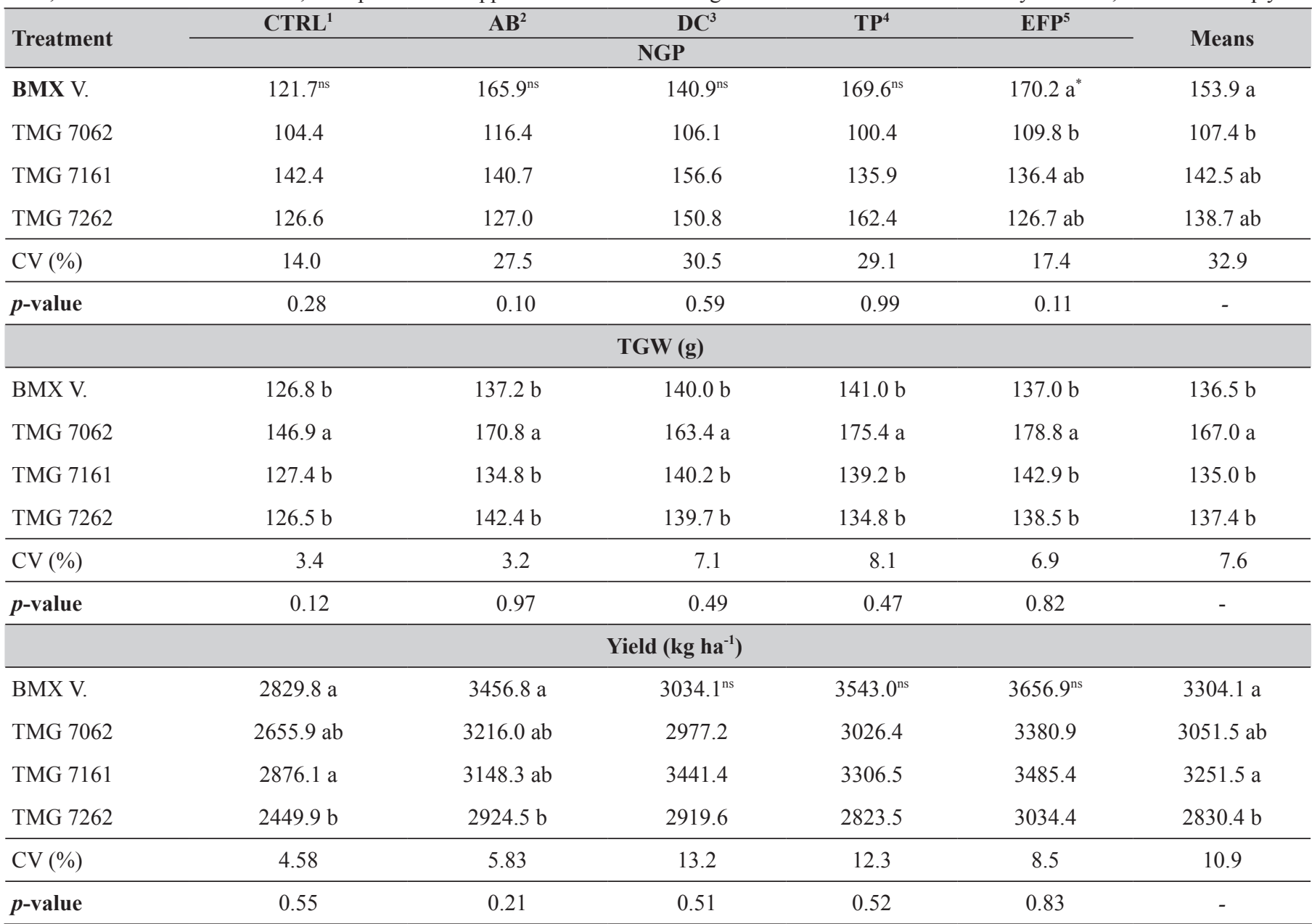

"Mean values followed by the same lowercase letter in the column do not differ statistically according to Tukey's test at $5 \%$ probability level. ${ }^{\text {ns }}$ not significant at $5 \%$ level; CV (\%), coefficient of variation. ${ }^{1}$ Control (CTRL); ${ }^{2}$ azoxistrobin + benzovindiflupyr (AB); ${ }^{3}$ difenoconazole + cyproconazole (DC); ${ }^{4}$ trifloxistrobin + prothioconazole (TP); ${ }^{5}$ epoxiconazole + fluxapyroxad + pyraclostrobin (EFP). 


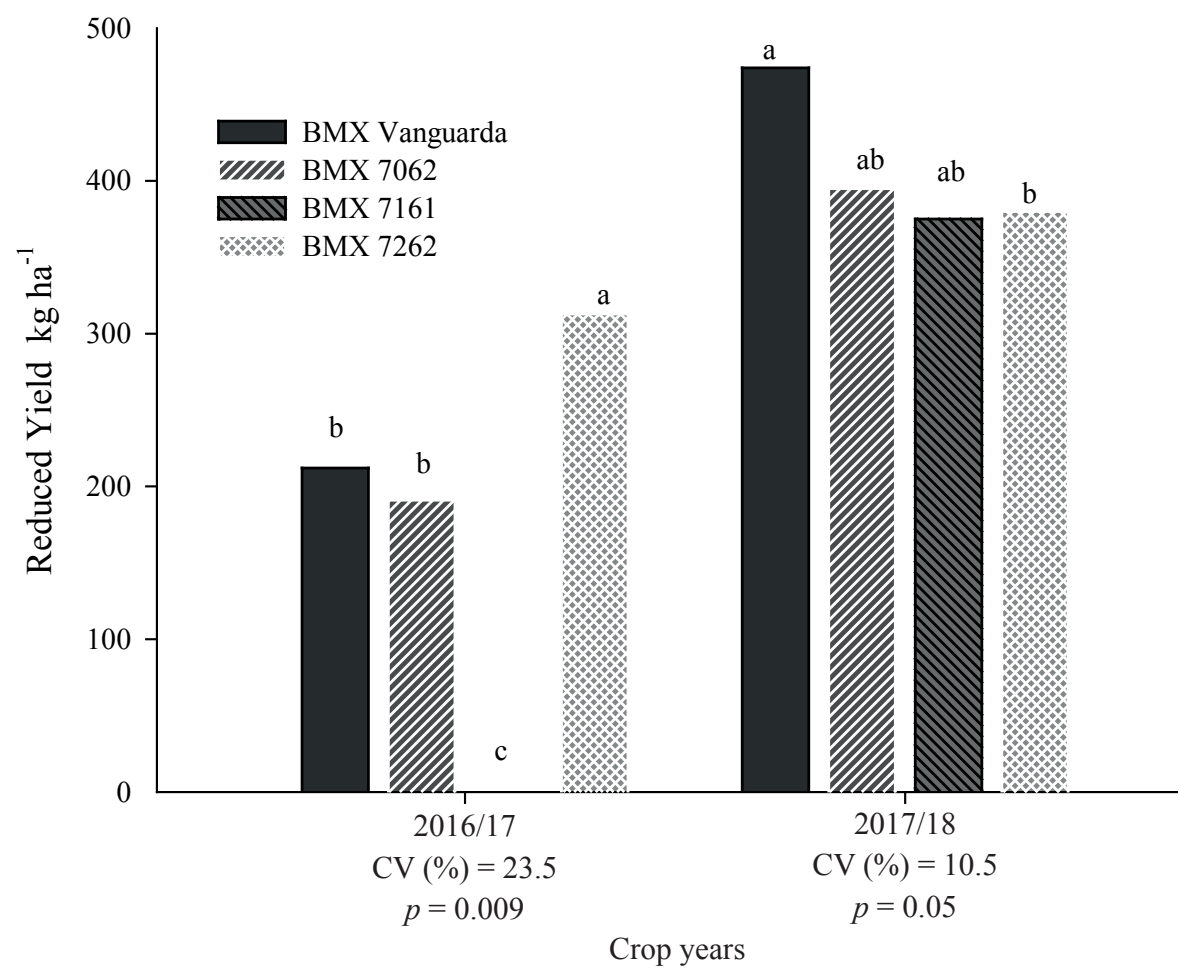

Figure 2. Yield reduction $\left(\mathrm{kg} \mathrm{ha}^{-1}\right)$ due to Asian soybean rust for the cultivars BMX Vanguarda, TMG 7062, TMG 7161 and TMG 7262. Lowercase letters indicate the average yield of cultivars, compared to control treatments (absence of fungicide application), in 2016/17 and 2017/18 crop years.

the absence of fungicide application, this cultivar showed the highest yield (474.3 $\left.\mathrm{kg} \mathrm{ha}^{-1}\right)$ in the last evaluated crop year (Table 3).

In genetic breeding for disease resistance, it is important to know all diversity of Phakopsora pachyrhizi, as well as its virulence and how soybean cultivars react to the pathogens in the different grainproducing regions (22). In the field, Maphosa et al. (16) verified that such variability, isolate (genotype) x year (season), had a great impact on the severity of ASR. Therefore, there may be a greater effect of the environment on the disease severity (17).

Resistance characterization is closely associated with lesion density, latency period and proportion of sporulated lesions, which directly affect the disease progression $(16,17)$. Kawashima et al. (12) obtained soybean immune to ASR after cloning the R gene CcRppl from Guandu bean (Cajanus cajan). This study highlighted that plants belonging to the same botanical family of soybean (Fabaceae) can provide resistance genes against P. pachyrrizi, constituting an important source of genetic variability.

The superiority of fungicides in mixtures over triazole alone was evident and similar results have been reported by Garcés-Fiallos \& Forcelini (8), thus representing lower sensitivity of the pathogen to triazoles. This behavior also occurred in trials conducted by Godoy et al. (9), where cyproconazole and tebuconazole-based fungicides provided control of $18 \%$ and $23 \%$, respectively, while the highest ASR control percentages were found for mixtures of fungicides such as: azoxystrobin + benzovindiflupyr (67\%), trifloxystrobin + prothioconazole $(55 \%)$, and epoxiconazole + fluxapyroxad + pyraclostrobin (68\%) (9).

Even with the sensitivity of the fungus to fungicides of the SDHI group (succinate dehydrogenase inhibitors) reported for 2016/17 crop year (9), azoxystrobin + benzovindiflupyr maintained similar control in both crop years evaluated in the present study $(2016 / 17$ and 2017/18).

Dalla Lana et al. (5), through a meta-analytical model that considered more than 200 field studies carried out between 2004/05 and 2013/14 crop years, evaluated the annual rate of decline in ASR control by some fungicides. They verified that fungicides with the highest percentage reductions per year $\left(\mathrm{pp}^{-1}\right.$ year) were: tebuconazole (7.7 $\mathrm{pp}^{-1}$ year), azoxystrobin $\left(5.4 \mathrm{pp}^{-1}\right.$ year $)$ and cyproconazole (4.2 $\mathrm{pp}$ $\left.{ }^{1}\right)$. Although smaller, they also observed a decline for the picoxystrobin + cyproconazole mixture $\left(2.5 \mathrm{pp}^{-1}\right.$ year $)$.

The reasons for the decline in ASR control may be related to the emergence of $P$. pachyrhizi populations with specific alterations responsible for the loss of sensitivity to both DMI (ergosterol inhibitors) and QoI (quinone outside inhibitors) fungicides, as well as SDHIs. Resistance emergence events are directly linked to the continuous use of the same active ingredient, submitting the fungicide between 8 and 10 pathogen cycles in only one crop cycle $(5,10,21)$.

Regarding yield components, Melo et al. (18) detected a difference in TGW among cultivars but no significant difference in yield, with and without fungicide application. Among cultivars, TGW differentiation is mostly due to genetic background and, between crop years, the difference observed for the same treatments could be attributed mainly to the lack of precipitation in 2017/18 crop year.

To develop resistant and/or tolerant materials, selection of soybean genotypes based on disease development and yield traits like e higher NGP and TGW under high ASR inoculum pressure is a promising alternative (15). Therefore, the genotypes should be exposed to different environments and crop years to evaluate the 
characteristics of genetic resistance against different dynamics of Phakopsora pachyrhizi inoculum.

Therefore, integration of management methods plays an important role in reducing the selection pressure on P. pachyrhizi. Genetic resistance combined with chemical control reduces the loss of fungicide efficiency for ASR control. Thus, integrated tools will certainly provide greater effectiveness in controlling ASR.

\section{REFERENCES}

1. Agrios, G.N. Plant pathology. 5.ed. Oxford: Academic, 2005. 922p.

2. BRASIL. Regras para análise de sementes. Brasília: Mapa/ACS, 2009. 399p.

3. Campbell, C.L; Madden, L.V. Introduction to plant disease epidemiology. $1^{\text {st }}$. ed. New York: Wiley-Blackwell, 1990. 560p.

4. Canteri, M.G.; Koga, L.J.; Godoy, C.V. Escala diagramática para estimar desfolha provocada por doenças em soja. In: Congresso Brasileiro de Soja, $4^{\circ}, 2006$, Londrina. Anais. Londrina: Embrapa, 2006, p.106.

5. Dalla Lana, F.; Paul, P.A.; Godoy, C.V.; Utiamada, C.M.; Silva, L.H.C.; Siqueri, F.V.; Juliatti, F.C. Forcelini. C. A.; Jaccoud-Filho, D. S.; Mie guel-Wruck, D. S.; Borges,, E. P.; Campos, H. D.; Nunes, J.; Carneiro, L. C.; Canteri, M. G.; Ito, M. F.; Meyer, M. C.; Martins, M. C.; Balardin, R. S.; Furlan, S. H.; Carlin, V. J.; Del Ponte, E. Meta-analytic modeling of the decline in performance of fungicides for managing soybean rust after a decade of use in Brazil. Plant Disease, Saint Paul, v.102, n.4, p. 807-817, 2018.

6. EMBRAPA. Sistema brasileiro de classificação de solos. $3^{\text {rd }}$ ed. Brasília: Embrapa, 2013. 353p.

7. Farias, J.R.B.; Nepomuceno, A.L.; Neumaier, N. Ecofisiologia da soja. Londrina: Embrapa, 2007. 9p. (Circular técnica 48).

8. Garcés-Fiallos, F.R; Forcelini, C.A. Comparative control of soybean rust by a triazol fungicide or a mix of triazol + strobylurin. Bioscience Journal, Uberlândia, v.29, n.4, p. 805-815, 2013.

9. Godoy, C. V.; Utiamada, C. M.; Meyer, M. C.; Campos, H. D.; Lopes, I. de O. N.; Forcelini, C. A.; Pimenta, C. B.; Jaccoud Filho, D. S.; Moreira, E. N.; Borges, E. P.; Andrade Junior, E. R. De; Siqueri, F. V.; Juliatti, F. C.; Favero, F.; Feksa, H. R.; Araujo Junior, I. P.; Grigolli, J. F. J.; Nunes Junior, J.; Belufi, L. M. De R.; Carneiro, L. C.; Silva, L. H. C. P.; Sato, L. N.; Canteri, M. G.; Volf, M. R.; Goussain, M.; Debortoli, M. P.; Martins, M. C.; Balardin, R. S.; Furlan, S. H.; Madalosso, T.; Carlin, V. J.; Venancio, W. S. Eficiência de fungicidas para o controle da ferrugem-asiática da soja, Phakopsora pachyrhizi, na safra 2016/17: resultados sumarizados dos ensaios cooperativos. Londrina: Embrapa, 2017. 129p. (Circular técnica 129).

10. Godoy, C.V.; Seixas, C.D.S.; Soares, R.M.; Marcelino-Guimarães, F.C.; Meyer, M.C.; Costamilan, L.M. Asian soybean rust in Brazil: past, present, and future. Pesquisa Agropecuária Brasileira, Brasília, v.51, n.5, p.407-421, 2016.

11. Instituto Nacional De Meteorologia (INMET). Available at: <http://www. inmet.gov.br/portal/Andgt>. Acessed on: 20 nov. 2018

12. Kawashima, C.G.; Guimarães, G.A.; Nogueira, S.R.; Maclean, D.; Cook, D.R.; Steuernagel, B.; ... \& Brommonschenkel, S.H. A pigeonpea gene confers resistance to asian soybean rust in soybean. Nature Biotechnology, London, v.34, n.6, p.661-665, 2016.

13. Klosowski, A.C.; May de Mio, L.L.; Miessner, S., Rodrigues, R.; Stammler, G. Detection of the F129L mutation in the cytochrome b gene in Phakopsora pachyrhizi. Pest Management Science, NewYork, v. 72, n. 6, p. 1211-1215, 2016

14. Langenbach, C.; Campe, R.; Beyer, S.F.; Mueller, A.N.; Conrath, U. Fighting asian soybean rust. Frontiers in Plant Science, Switzerland, v.7, p.1-13, 2016.

15. Lima, W.F.; Prete, C.E.C.; Ribeiro, A.S.; Toledo, J.F.F. Resistência da soja à ferrugem-asiática avaliada pela análise da produtividade de grãos. Summa Phytopathologica, Botucatu, v.38, n.1, p.73-78, 2012.

16. Maphosa, M.; Talwana, H.; Tukamuhabwa, P. Assessment of comparative virulence and resistance in soybean using field isolates of soybean rust. Journal of Agricultural Science, Toronto, v.5, n.5, p.249-257, 2013.

17. Martins, J.A.S; Juliatti, F.C. Genetic control of partial resistance to Asian soybean rust. Acta Scientiarum Agronomy, Maringá, v.36, n.1, p.11-17, 2014.

18. Melo, C.L.P.; Roeseii, A.D.; Goulart, A.C.P. Tolerância de genótipos de soja à ferrugem asiática. Ciência Rural, Santa Maria, v.45, n.8, p.1353-1360, 2015.

19. Moura, B.; Boller, W.; Deuner, C.C. In vitro determination of fungicide inhibitory concentration for Phakopsora pachyrhizi isolates. Summa Phytopathologica, Botucatu, v.42, n.4, p.1-2, 2016.

20. R Core Team. R: A language and environment for statistical computing. R Foundation for Statistical Computing, Vienna, Austria, 2017.

21. Reis, E.M.; Reis, A. C.; Zanatta, M.; Silva, L.H.C.P.; Siqueri, F.V.; Silva, J.R.C. Evolução de redução de sensibilidade de Phakopsora pachyrhizi a fungicidas e estratégias para recuperar a eficiência do controle. $3^{\text {rd }}$ ed. Passo Fundo: Berthier, 2017. 104 p.

22. Yamanaka, N.; Lemos, N.G.; Uno, M.; Akamatsu, H.; Yamaoka, Y.; Abdelnoor, R.V.; Braccini, A.L.; Suenaga, K. Resistance to Asian soybean rust in soybean lines with the pyramided three Rpp genes. Crop Breeding and Applied Biotechnology, Viçosa, v.13, n.1, p.75-82, 2013. 